\title{
Factors Related to the Complaints of Musculoskeletal Disorders of Shelving Staff
}

\author{
Faktor yang Berhubungan dengan Keluhan Musculoskeletal Disorders pada \\ Petugas Shelving Book
}

\author{
Yovian Treesyanova \\ Dr. Soetomo Regional Public Hospital, Surabaya \\ Jalan Mayjend Prof. Dr. Moestopo No. 6-8, Gubeng, Surabaya, East Java 60286, Indonesia
}

\begin{abstract}
Introduction: Every worker is exposed to the risk of occupational accidents or diseases when working. Awkward working postures are the postures that cause body parts to detach from its natural postures that can result in the complaints of musculoskeletal disorders (MSDs). This research aims to analyze the factors related to the complaints of MSDs suffered by the shelving staff in the library and reading room at Universitas Airlangga Surabaya. Methods: This research is observational research that applies a cross-sectional design. The sample of this research consists of 27 people chosen by using the total population method. The data regarding the individual characteristics and the complaints of MSDs are obtained through interviews and standardized-questionnaires. The data on working postures are analyzed by referring to the Rapid Entire Body Assessment (REBA) method, while the data on the complaints of MSDs are scrutinized by implementing the Nordic Body Map (NBM) method. Results: Indicate that most of the shelving staff are suffered from a very high-risk level of MSDs (40.7\%). Other than that, it is noticed that the working postures performed by the shelving staff are risky, for instance, squatting (high-risk level), bowing (high-risk level), standing (moderate-risk level), standing with arms stretching (very high-risk level), and standing with arms stretching while tiptoeing (very high-risk level). The collected data is analyzed by using the Spearman correlation test. Conclusion: It can be stated that the strongest factor causing the occurrence of MSDs is the years of service $(\mathrm{r}=0.803)$ with a positive correlation, which means that the longer the years of service, the higher the risk to suffer from MSDs.
\end{abstract}

Keywords: complaints of musculoskeletal disorders, individual factors, shelving staff

ABSTRAK

Pendahuluan: Pekerja dalam melakukan pekerjaannya berisiko mengalami kecelakaan ataupun penyakit akibat kerja. Sikap kerja yang tidak alamiah merupakan sikap kerja yang menyebabkan posisi bagian tubuh menjauhi posisi alamiahnya sehingga menyebabkan pekerja mengalami keluhan Musculoskeletal Disorders (MSDs). Penelitian ini bertujuan untuk mempelajari faktor yang berhubungan dengan keluhan MSDs pada petugas Shelving Book di Perpustakaan dan Ruang Baca Universitas Airlangga Surabaya. Metode: Penelitian ini adalah penelitian observasional dengan pendekatan cross sectional. Sampel pada penelitian ini 27 orang. Pengambilan sampel pada penelitian ini dilakukan dengan cara total population. Data karakteristik individu dan keluhan MSDs diperoleh melalui wawancara kepada responden dan pengisian kuesioner yang distandarisasi. Data posisi kerja dianalisis menggunakan Rapid Entire Body Assessment (REBA), sedangkan data keluhan MSDs dianalisis menggunakan metode Nordic Body Map (NBM). Hasil: menunjukkan sebagian besar petugas Shelving Book mengalami keluhan MSDs tingkat risiko sangat tinggi (40,74\%) dan posisi kerja yang dilakukan terdiri dari posisi kerja jongkok (level risiko tinggi), bungkuk (level risiko tinggi), berdiri (level risiko sedang), berdiri dengan tangan menjangkau ke atas (level risiko sangat tinggi), dan berdiri dengan tangan menjangkau keatas serta kaki berjinjit (level risiko sangat tinggi). Data yang didapatkan dianalisis menggunakan uji kolerasi Spearman. Simpulan: Faktor penyebab terjadinya Musculoskeletal Dissorders yang memiliki hubungan paling kuat adalah masa kerja dari pekerja $(r=0,803)$ dengan arah hubungan positif, yang artinya semakin lama masa kerja petugas Shelving Book, maka makin tinggi pula risiko untuk mengalami keluhan MSDs.

Kata kunci: faktor individu, keluhan musculoskeletal disorders, petugas shelving

(C)2019 IJOSH. Open access under CC BY NC-SA license doi: 10.20473/ijosh.v8i3.2019.346-353. Received July 10, 2018, received in revised form January 23, 2019, Accepted November 04, 2019, Published: December 2019 
Author for Correspondence:

Yovian Treesyanova

Email: yovi.treesyanova@gmail.com

Telephone: +6282231044940

\section{INTRODUCTION}

Working ergonomically will provide a sense of comfort, avoid fatigue and unnecessary movements, as well as give a minimum effort to acquire maximum results of work. Moreover, it is common for workers to be at risk of experiencing occupational accidents or diseases when working, especially caused by awkward working postures. Awkward working postures can be defined as postures where body parts are detached from its natural postures, for example, over-reached arms, bending, and other non-ergonomic postures (Tarwaka, H.A and Sudiajeng, 2004).

There are various types of ergonomic problems discovered in a workplace, particularly those that are related to muscle strength and endurance, for instance, musculoskeletal disorders (MSDs). MSDs are disorders on the soft tissues and nervous systems. The working activities performed by operational workers are noticed problematic, for example, the working activities carried out by the shelving staff in the libraries and reading rooms at Airlangga University which comprise placement and rearrangement of library materials based on each book call-number, alphabet, et cetera.

The works performed by the shelving staff require non-ergonomic postures, such as book alignment on a 5-level shelf that forces them to squat with unstable leg postures. The other postures discovered made by shelving staff comprise of bending with arms reach above the head when putting books on the shelf, tiptoeing while reaching arms, and carrying heavy books at the same time.

If those postures are continuously made in a long period of time, the shelving staff may suffer from diseases caused by awkward body postures. Moreover, those postures can also trigger the occurrence of disorders in several limbs, such as disorders in soft tissues, muscles, tendons, ligaments, joints, and nervous systems, which also known as MSDs. Hence, it has been confirmed that shelving staff has a high risk of suffering from complaints of MSDs.

\section{METHODS}

This research is observational research completed by observation and without any special treatment to the respondents nor the research objects. Besides, this research was carried out by implementing a cross-sectional approach since the observation of the variables was completed in a certain period of time. The sampling technique used in choosing the research sample was a total population technique, which covers all 27 -shelving staff in the libraries and the reading rooms at Universitas Airlangga with the following inclusion criteria: The respondents do not suffer from muscle and joint disorders; The respondents do not smoke; The respondents work as librarians in the shelving section.

There are two variables of this research; dependent and independent variables. The dependent variable is the complaints of MSDs, while the independent variable is the individual factors, which cover the age, working duration, and years of service.

Both the primary and secondary data were obtained from November 2017 until February 2018 in all libraries and reading rooms at Airlangga University, Surabaya. The primary data was obtained through interviews to identify the age, working duration, and years of service; REBA observation sheets; and NBM questionnaires. Meanwhile, the secondary data was in the form of files and documents regarding the name and a total number of the shelving staff, as well as the profile of all libraries (Campus A, Campus B, and Campus $\mathrm{C}$ libraries) and reading rooms in all faculties at Airlangga University, Surabaya.

All of the data is presented descriptively. In other words, the data obtained from questionnaires distribution, interviews, and measurement results are scrutinized in the form of table, narration, and crosstabulation in order to simplify the description of the results. In addition, to figure out the correlation strength between variables, the Spearman rho correlation test was implemented.

\section{RESULTS}

\section{The Individual Factors of the Respondents}

The respondents' characteristics are features that cannot be manipulated. In this research, the variables used to identify the respondents' characteristics are age, working duration, and years of service. Those characteristics are presented in Tables 1, 2, and 3.

Age is the life span of a worker calculated from the time the worker was born until the time this research was conducted. From four age categories, it 
was noticed that in this research, the majority of the respondents are in the age group of 29-36 years old, which is as many as 9 people $(33.3 \%)$.

Working duration is the workers' time in completing working activities within a day. Based on the research, it was recognized that $50 \%$ of the respondents, which are as many as 15 people, work for $>8$ hours a day.

Years of service can be defined as the length of time the respondents had worked calculated from the time they started working until the time when this research was conducted. From the data collection, it was noticed that from a total of 27 respondents, 12 of them $(44.44 \%)$ had worked for $<5$ years by the time this research was completed.

\section{The Working Postures of the Respondents}

The assessment of the working postures of the respondents was carried out by implementing the Rapid Entire Body Assessment (REBA) method. Furthermore, the assessment was completed based on the scoring that was put into Groups A, B, and C. The total score obtained was used to determine the risk level of injury by determining the level of corrective action required and intervening, so the risk that may arise can be reduced.

Figure 1 until Figure 6 are examples of the assessment in determining the risk level of working postures made by the shelving staff. The first

Table 1. The Age of the Shelving Staff in the Libraries and Reading Rooms at Universitas Airlangga in 2018

\begin{tabular}{ccc}
\hline Age (Years old) & Frequency (n) & Percentage (\%) \\
\hline $19-28$ & 6 & 22.2 \\
$29-36$ & 9 & 33.3 \\
$37-45$ & 7 & 25.9 \\
$46-54$ & 5 & 18.5 \\
\hline Total & 27 & 100 \\
\hline
\end{tabular}

Table 2. The Working Duration of the Shelving Staff in the Libraries and Reading Rooms at Universitas Airlangga in 2018

\begin{tabular}{ccc}
\hline $\begin{array}{c}\text { Working } \\
\text { Duration (hour) }\end{array}$ & Frequency (n) & $\begin{array}{c}\text { Percentage } \\
(\%)\end{array}$ \\
\hline$\leq 8$ & 12 & 44.44 \\
$>8$ & 15 & 55.56 \\
\hline Total & 27 & 100 \\
\hline
\end{tabular}

Table 3. The Years of Service of the Shelving Staff in the Libraries and Reading Rooms at Universitas Airlangga in 2018

\begin{tabular}{ccc}
\hline $\begin{array}{c}\text { Years of Service } \\
\text { (years) }\end{array}$ & Frequency (n) & $\begin{array}{c}\text { Percentage } \\
(\%)\end{array}$ \\
\hline$\leq 5$ & 12 & 44.44 \\
$6-10$ & 5 & 18.52 \\
$>10$ & 10 & 37.04 \\
\hline Total & 27 & 100 \\
\hline
\end{tabular}

group, Group A, consists of the body, neck, and leg postures.

Figure 1 showed the posture of body extension by forming an angle of $18^{\circ}$, thus, the body score is 2 . However, since the body twists, 1 was added. As a result, the total score for the body posture was 3 . In Figure 2, the neck posture is extended by $>20^{\circ}$ and was given a score of 2 as its final score.

From Figure 3, it can be seen that the leg posture of the respondent is not considered a stable posture due to the fact that one leg is not wellsupported. Therefore, the score of the leg posture was 2 without any additional score.

After obtaining all scores of Group A (body, neck, and leg postures), those scores were listed in the table and produced a score of 5. The score obtained in Group A then added to the loading score to get the total score of Group A, which was 0 , providing that the weight sustained by the respondent was $<5 \mathrm{kgs}$. Accordingly, the total score of Group A was 5, obtained from 5 (scores of body, neck, and leg postures) added by 0 (loading score).

The upper arm posture made by the respondent showed flexion and formed an angle of $42^{\circ}$. Therefore, this posture obtained a score of 2. Nonetheless, when making that posture, the respondent lifted his shoulder, twisted his arm, and lifted his arm away from the body. For that reason, an additional changing score of 2 was given. As a result, the score for the upper arm posture was 4 .

The lower arm posture of the respondent obtained a score of 2 since the posture formed a flexion of $27^{\circ}$. In other words, it can be stated that the flexion of the lower arm posture was around $<60^{\circ}$. As a result, this posture attained a score of 4 .

Figure 6 displayed the wrist posture of the respondent. It can be noticed that it formed an angle of $23^{\circ}$ which obtained a score of 2 . However, the wrist of the respondent was spotted twisting to the left, which made it attained an additional changing 
score of 1 . Thus, the score of the wrist posture was 3.

After all scores of Group B were acquired (scores of the upper arm, lower arm, and wrist postures), it was then listed in Group B table score and obtained a score of 7 . Next, this score was added to the loading score of Group B, which was 0 , providing that the loading was considered ideal. Consequently, those two scores were added to obtain a score of 7 as the total score of Group B.

As for the next step, the total scores of Groups A and B were presented in Table score C (Group C) to determine the action level and risk level category. As a result, it was obtained a score of 9 as the score of Group C. This score was then also added to the score of muscle activity to obtain the grand score of Group C. Accordingly, a score of 12 was obtained from the addition of 9 (Group $C$ score) to 3 (the REBA grand score). Finally, this score was used to identify the action level and the risk category level as presented in Table 4.

Table 4 displayed that the standing posture with arms reaching above the head and tiptoeing

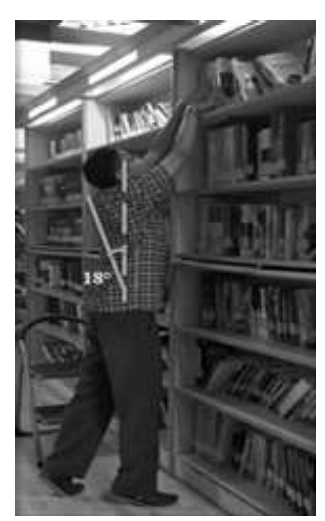

Figure 1. Scoring for the Body Posture

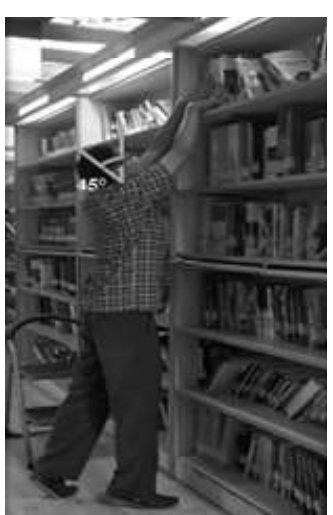

Figure 2. Scoring for the Neck Posture

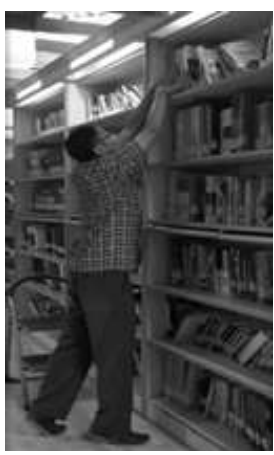

Figure 3. Scoring for the Leg Posture considered a very high-risk level posture. In other words, the corrective actions for this working posture need to be performed as soon as possible. Besides, the same step was carried out to the assessment of the other four working postures which results can be seen in Table 5.

\section{The Complaints of MSDs Suffered by the Respondents}

The complaints of MSDs can be termed as a complaint that occurs in the skeletal muscles that range from mild to very severe complaints. The complaints can be in the forms of uncomfortable feelings, pains, fatigue, and many more. The complaints of MSDs suffered by the respondents that had been assessed by the instrument of Nordic Body Map (NBM) are displayed in Table 6 .

Based on the analysis of the complaints of MSDs suffered by the respondents who work as

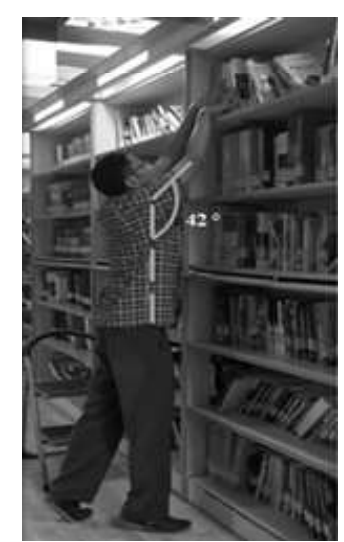

Figure 4. Scoring for the Upper Arm Posture

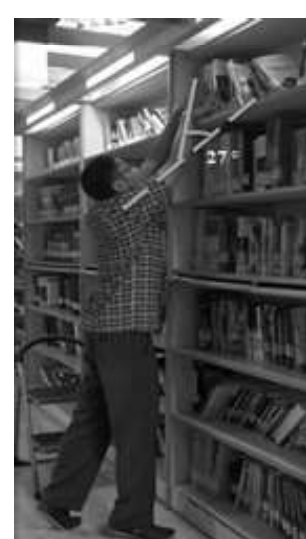

Figure 4. Scoring for the Lower Arm Posture

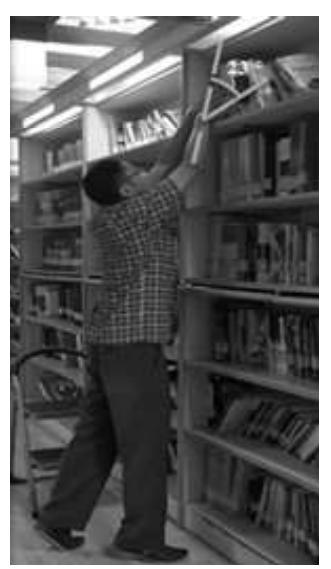

Figure 6. Scoring for the Wrist Posture 
Table 4. Action Level and Risk Level

\begin{tabular}{|c|c|c|c|}
\hline $\begin{array}{l}\text { Total } \\
\text { Score }\end{array}$ & $\begin{array}{l}\text { Action } \\
\text { Level }\end{array}$ & Risk Level & Action \\
\hline 1 & 0 & Very Low & No action needed \\
\hline $2-3$ & 1 & Low & Action may be needed \\
\hline $4-7$ & 2 & Moderate & Action is needed \\
\hline $8-10$ & 3 & High & $\begin{array}{l}\text { Immediate action is } \\
\text { needed }\end{array}$ \\
\hline $11-15$ & 4 & Very High & $\begin{array}{l}\text { Action is needed as } \\
\text { soon as possible }\end{array}$ \\
\hline
\end{tabular}

shelving staff in the libraries and reading rooms at Airlangga University, it was attained that all of the respondents had felt the complaints in the skeletal muscles. The majority of the respondents suffered from a high-level of MSDs, which is as many as 11 people $(40.74 \%)$. Furthermore, most of the complaints suffered by the respondents were in 30 body parts in the right upper arm, right lower arm, left lower arm, and right leg. Apparently, these complaints, especially in lower and upper arms, occurred due to the activity of book shifting on the shelves to provide more spaces. In the meantime, the complaint felt in the left lower arm was because the staff put the books on it before placing the books on the shelf. As for the last complaint, that is a complaint felt in the right leg, was caused by the activity of placing the books on the top shelf, when the staff needed to tiptoeing for a certain period of time.

\section{The Complaints of MSDs based on the Respondents' Age}

The respondents in the age group of 29-36 years old were noticed to have higher complaints of MSDs than the respondents in the other age groups, which is as many as 9 people (33.3\%), with nobody had mild and moderate levels of complaints. Meanwhile, the high-risk and very high-risk levels were suffered by 6 and 3 people, respectively. Moreover, based on the Spearman correlation test, it was obtained that the correlation between the age and the complaints of MSDs attained a score of 0.512 .

Furthermore, referring to the analysis that has been carried out, it was discovered that there is a strong and positive correlation between the age and the complaints of MSDs since the coefficient $r$ is positive. This also indicated that the older the staff, the higher the level of MSDs complaints.
Table 5. The Working Postures of the Shelving Staff in the Libraries and Reading Rooms at Universitas Airlangga in 2018

\begin{tabular}{cccc}
\hline $\begin{array}{c}\text { Working } \\
\text { Posture }\end{array}$ & $\begin{array}{c}\text { Total } \\
\text { Score }\end{array}$ & Risk Level & $\begin{array}{c}\text { Corrective } \\
\text { Action }\end{array}$ \\
\hline Squatting & 10 & High & $\begin{array}{c}\text { Immediate action } \\
\text { is needed }\end{array}$ \\
Bending & 8 & High & $\begin{array}{c}\text { Immediate action } \\
\text { is needed }\end{array}$ \\
$\begin{array}{c}\text { Standing } \\
\text { Standing } \\
\text { with the } \\
\text { arms }\end{array}$ & 5 & Moderate & $\begin{array}{c}\text { Action is needed } \\
\text { Action is needed } \\
\text { as soon as } \\
\text { possible }\end{array}$ \\
$\begin{array}{c}\text { Seaching up } \\
\text { Standing } \\
\text { with the } \\
\text { arms }\end{array}$ & 11 & Very High & $\begin{array}{c}\text { Action is needed } \\
\text { as soon as } \\
\text { possible }\end{array}$ \\
reaching up \\
and tiptoeing
\end{tabular}

Table 6. The Level of Complaints of MSDs of the Shelving Staff in the Libraries and Reading Rooms at Universitas Airlangga in 2018

\begin{tabular}{ccc}
\hline $\begin{array}{c}\text { Level of MSDs } \\
\text { Complaints }\end{array}$ & Frequency (n) & Percentage (\%) \\
\hline Mild & 2 & 7.41 \\
Moderate & 6 & 22.22 \\
Severe & 8 & 29.63 \\
Very Severe & 11 & 40.74 \\
Total & 27 & 100 \\
\hline
\end{tabular}

\section{The Complaints of MSDs based on the Respondents' Working Duration}

Based on the analysis, it was noticed that the respondents with a working duration of $>8$ hours per day suffered from a higher-risk level of MSDs, which is as many as 15 people $(55.56 \%)$. In addition, no one was found healthy, 2 people suffered from a moderate-risk level of MSDs, 5 people suffered from a high-risk level of MSDs, and 8 people suffered from a very high-risk level of MSDs.

he result of the correlation analysis between the working duration and the complaints of MSDs attained the coefficient $r$ of 0.401 . In other words, it can be declared that both variables have a moderate positive correlation. Additionally, it can also be affirmed that the longer the working duration, the higher the risk of experiencing the complaints of MSDs. 


\section{The Complaints of MSDs based on the Respondents' Years of Service}

It was reported that 10 of the respondents (37.04\%) had served for more than 10 years as shelving staff. From that number, 2 of them suffered from a high-risk level of MSDs, while the other 8 suffered from a very high-risk level of MSDs.

The correlation score between the years of service and the complaints of MSDs was quite high, which was 0.805 . Thus, it can be assumed that there is a very strong and positive correlation between the years of service and the complaints of MSDs suffered by the shelving staff, which means that the longer the years of service, the higher the risk level of suffering from MSDs.

\section{DISCUSSION}

\section{The Complaints of MSDs based on the Respondents' Age}

The age of the respondents can be defined as the life span calculated from the time when the respondent was born until the time when this research was conducted. According to Bridger (2003), the older someone, the higher the chance of the decrease of bone elasticity, which results in the occurrence of the MSDs complaints. The degeneration process of the bones is in accordance with the increase of the age. Normally, this condition starts when someone reaches the age of 30 . This degeneration process can be in the form of tissue damage and the decrease of body liquid.

After analyzing all variables, it was known that there is a moderate correlation between the age and the complaints of MSDs. Besides, the age and the complaints of MSDs have a positive correlation, which means that the older the staff, the higher the risk level of MSDs. Tarwaka (2015) affirmed that the first complaint of MSDs is usually felt by someone above 30 years old. Then, as the number increases, the risk level will also be higher. Apparently, this due to the fact that the muscle strength and endurance of middle-aged people do decrease, which increases in the complaints of MSDs.

The results of this research are in accordance with the research conducted by Pratama, Tarwaka and Suryanata (2015), which explained that there is a significant correlation between age and complaints of MSDs. Mardiman (2001) affirmed that mostly, muscle pains are suffered by people in productive.
The productive ages that ranges from 15-64 years old (International Labour Organization, 2013). Furthermore, the majority of the shelving staff who took part in this research $(33.3 \%)$ were in the age group of 29-36 years old, which can also be stated that they were still in their productive age.

\section{The Complaints of MSDs based on the Respondents' Working Duration}

Working duration is calculated from the time a worker starts working until the time she/he finishes the work. The working duration can be classified into 2 categories, namely normal working hours $(<8$ hours per day) and overworking hours ( $>8$ hours per day) (Jalajuwita and Paskarini, 2015). The correlation analysis between the working duration and the complaints of MSDs generated a result of moderate correlation. Generally, the working duration of a worker ranges between 6-8 hours per day, while the rest 16-18 hours are the hours allocated to the personal life. Additionally, it is believed that a worker can work productively if $\mathrm{s} / \mathrm{he}$ works for about 40-50 hours per week (Suma'mur, 1996).

However, most of the respondents work for more than 8 hours per day. The working hour for the respondents in the libraries and reading rooms at Universitas Airlangga starts from 08:00 until 17:00 with limited break time. In fact, the workers who work in the reading room in the Faculty of Economics and Business start their working durations from 08:00 and ends at 20:30. These working durations experienced by the same workers every day and when there are more visitors might trigger the repetition of working attitudes. Thus, if the respondents work for 8 hours per day, it is possible that they will undergo the complaints of MSDs.

According to those reasons, this research is similar to the research authored by Wijayanti (2013) on the correlation between the complaints of MSDs and the farmers' working environment, working postures, and years of service. As a result, it was obtained that there is a correlation between the farmers' years of service and the complaints of MSDs. Besides, referring to the research carried out by Utami, Karimuna and Jufri (2017), it was also attained that there is a correlation between the years of service and the complaints of MSDs suffered by the rice paddy farmers in Ahuhu Village in 2017. 


\section{The Complaints of MSDs based on the Respondents' Years of Service}

Years of service can be calculated from the time a worker first starts working until the time when this research was completed. Hardono and Kurniawan (2017) affirmed that years of service can be categorized into $<5$ years, $6-10$ years, and $>10$ years.

The results of the analysis showed that there is a very strong correlation between the years of service and the complaints of MSDs suffered by the shelving staff in the libraries and reading rooms at Universitas Airlangga. Furthermore, the correlation was noticed positive, which can be assumed that the longer the years of service, the higher the risk level of the shelving staff to suffer from MSDs.

Tarwaka (2015) explained that the complaints of MSDs will increase when there is an increase in the years of service of a worker, along with the tediousness both physically and psychologically. In addition, it was described that years of service is the most influential factor that increases the occurrence of MSDs, particularly for the works performed repetitively in a long period of time.

Referring to the results, this research is in line with the research piloted by Sulung and Mutia (2016), which concluded that there is a strong correlation between the years of service and the complaints of MSDs suffered by the unloading workers. Moreover, the research carried out by Rivai, Ekawati and Jayanti (2014) also affirmed that there is a strong correlation between the years of service and the complaints of MSDs suffered by the stone breakers.

\section{The Working Postures of the Respondents}

The working postures of the respondents were assessed by implementing the Rapid Entire Body Assessment (REBA) method to attain the final score to determine the risk category. Squatting posture obtained the final score of 10 , which made the posture to have a high-risk level of MSDs and need an immediate corrective action to the posture. In addition, this posture is made by the shelving staff when arranging the books on the first and second shelves. Thus, if there are many books on the first shelf to be arranged, the staff squat for a long time, which leads to the loss of balance when there is a sudden change in the posture.

Bending posture obtained the final score of 8 , which makes the posture considered a high-risk level posture that needs immediate corrective action to the posture. The book arrangement on the third shelf is carried out by bending due to the book catalog codes that are placed at the lower part of each book.

Standing posture obtained a final score of 5 . Thus, this posture had a moderate-risk level of MSDs and need a corrective action to the posture. The book alignment on the fourth shelf requires the shelving staff to stand. Hence, the standing posture is the posture in which the risk level is the lowest, compared to the other postures.

Standing posture with the arms reaching up had the final score of 11 , which placed this posture in a very high-risk level of MSDs and need a corrective action to the posture as soon as possible. This posture is made by the shelving staff when arranging the books on the fifth shelf since the shelf's position is above the shoulder of the shelving staff. Therefore, this posture required the staff to carry a certain load when arranging the shelf.

Standing posture with the arm reaching up and tiptoeing obtained a final score of 12 . Therefore, this posture was considered a very high-risk level working posture and need an immediate corrective action. This posture is made when arranging the books on the sixth shelf, which height is taller than the height of the shelving staff. Additionally, this posture is considered a non-ergonomic posture referring to the load borne by the shelving staff.

Several postures are considered as high-risk level postures since those are recognized as nonergonomic postures. Unfortunately, it discovered that almost all of the shelving staff are comfortable to be in non-ergonomic working postures. Evidently, this is caused by the lack of understanding of the effects initiated by those non-ergonomic postures, for example, the complaints of MSDs.

Every day, the shelving staff are obliged to tidy up and to arrange 300 until 400 books, depending on the number of visitors. Nonetheless, it was reported that day by day, the number of visitors increased, which results in the increase in the working intensity and repetitive working postures of the shelving staff. Besides, these non-ergonomic postures are also caused by the limited distance between one shelf and another, which may lead to an increase in the complaints of MSDs.

\section{CONCLUSION}

From the scrutinization that has been elucidated, it can be concluded that most of the shelving staff 
undergone a very high-risk level of MSDs (40.74\%) caused by several working postures, such as squatting (high-risk level), bending (high-risk level), standing (moderate-risk level), standing with the arm reaching up (very high-risk level), and standing with the arm reaching up and tiptoeing (very high-risk level). Additionally, the correlation test indicated that the working duration and the complaints of MSDs have a strong correlation, while the strong and moderate correlations are discovered between the age and years of service and the complaints of MSDs, respectively.

\section{ACKNOWLEDGMENT}

The authors would like to acknowledge the Heads of the Libraries in Campus A, Campus B, and Campus $\mathrm{C}$ of Airlangga University as well as the coordinators of the reading rooms in all faculties at Airlangga University for the permission and opportunity given to carry out this research. In addition, the authors are thankful for the shelving staff who are willing to be the respondents of this research and providing the information needed to complete this research.

\section{REFERENCES}

Bridger, R. . (2003) Introduction to Ergonomics. London: Taylor \& Francis Ltd.

Hardono, E. R. and Kurniawan, I. N. (2017) Peran Job Crafting terhadap Readiness for Organisational Change Karyawan. Scientific Article. Yogyakarta: Faculty of Psychology and Social Cultural Sciences, Universitas Islam Indonesia.

International Labour Organization (2013) 'The Prevention of Occupational Disease'. Geneva: International Labour Organization.

Jalajuwita, R. N. and Paskarini, I. (2015) 'Hubungan Posisi Kerja dengan Keluhan Muskuloskeletal pada Unit Pengelasan PT. X Bekasi', The Indonesian Journal of Occupational Safety and Health, 4(1), pp. 33-42.
Mardiman, S. (2001) Modulasi Nyeri dan Mekanisme Pengurangan Nyeri dengan Modalitas Fisioterapi. Surakarta: Universitas Negeri Sebelas Maret.

Pratama, D. H., Tarwaka and Suryanata, S. (2015) Hubungan antara Risiko Pekerjaan Manual Handling, Usia, dan Masa Kerja dengan Risiko Gangguan Sistem Muskuloskeletal pada Pekerja Bagian Perakitan Penulangan Besi Beton di PT. Wijaya Karya Beton Tbk. Boyolali. Scientific Article. Surakarta: Faculty of Health Sciences, Universitas Muhammadiyah Surakarta.

Rivai, W. T., Ekawati and Jayanti, S. (2014) 'Hubungan Tingkat Risiko Ergonomi Dan Masa Kerja Dengan Keluhan Muskuloskeletal Pada Pekerja Pemecah Batu', Jurnal Kesehatan Masyarakat (e-Journal), 2(3), pp. 227-231.

Sulung, N. and Mutia, W. (2016) 'Beban Angkut, Posisi Angkut, Masa Kerja Dan Umur Dengan Keluhan Muskuloskeletal Pada Pekerja Bongkar Muat', Jurnal Endurance, 1(2), pp. 63-74.

Suma'mur (1996) Higiene Perusahaan dan Kesehatan Kerja. Jakarta: CV. Haji Masagung.

Tarwaka (2015) Ergonomi Industri Dasar-Dasar Pengetahuan Ergonomi dan Aplikasi di Tempat Kerja. 2nd edn. Surakarta: Harapan Press.

Tarwaka, H.A, S. and Sudiajeng, L. (2004) Ergonomi untuk Keselamatan, Kesehatan Kerja dan Produktivitas. Surakarta: UNIBA PRESS.

Utami, U., Karimuna, S. R. and Jufri, N. (2017) 'Hubungan Lama Kerja, Sikap Kerja dan Beban Kerja dengan Muskuloskeletal Disorders (MSDs) pada Petani Padi di Desa Ahuhu Kecamatan Meluhu Kabupaten Konawe Tahun 2017', Jimkesmas (Jurnal Ilmial Mahasiswa Kesehatan Masyarakat), 2(6), pp. 1-10.

Wijayanti, T. S. (2013) Hubungan antara Nyeri Muskulosekeletal dengan Kondisi Stasiun Kerja dan Ukuran, serta Posisi Tubuh Petani. Scientific Article. Surabaya: Faculty of Social Science and Political Science, Universitas Airlangga. 